\title{
KOPING MASYARAKAT TAMBAKLOROK DAN ROWOSARI DI KOTA SEMARANG TERHADAP PERMASALAHAN PEMENUHAN AIR BERSIH
}

\section{COPING WITH THE PROBLEM OF PROVIDING CLEAN WATER IN TAMBAKLOROK AND ROWOSARI COMMUNITIES, SEMARANG CITY}

Erma Maulana Putri', Jawoto Sih Setyono

1 Departemen Perencanaan Wilayah dan Kota, Universitas Diponegoto; Jl.Prof.H.Soedarto, S.H.Tembalang, Tembalang, Kota Semarang; ermaulanaputri.ep@gmail.com

2 Departemen Perencanaan Wilayah dan Kota, Universitas Diponegoto; Jl.Prof.H.Soedarto, S.H.Tembalang, Tembalang, Kota Semarang; jawoto@gmail.com

Info Artikel:

- Artikel Masuk: 4 Januari 2019

\begin{abstract}
ABSTRAK
Isu dalam pemenuhan air bersih terkait dengan kesenjangan penyediaan air bersih dengan permintaan air bersih. Upaya adaptasi menghadapi kurangnya ketersediaan air bersih dikenal adanya istilah koping. Koping terhadap tekanan merupakan salah satu komponen dari kerentanan. Penelitian ini memiliki pertanyaan penelitian berkaitan dengan "bagaimana mekanisme koping masyarakat Kampung Tambaklorok dan Kelurahan Rowosari terhadap permasalahan pemenuhan air bersih?”. Tujuan penelitian ini adalah mengkaji mekanisme koping yang dilakukan oleh masyarakat Kampung Tambaklorok dan Kelurahan Rowosari dalam pemenuhan air bersih. Kampung Tambaklorok dan Kelurahan Rowosari merupakan dua wilayah di Kota Semarang yang memiliki permasalahan dalam pemenuhan air bersih. Pendekatan penelitian yang digunakan adalah metode penelitian survei dengan penyebaran kuisioner kepada masyarakat. Analisis yang digunakan dalam penelitian adalah statistik deskriptif. Hasil temuan studi yaitu terdapat perbedaan dan persamaan mekanisme koping masyarakat Kampung Tambaklorok dan Kelurahan Rowosari. Perbedaan mekanisme koping dinilai berdasarkan faktor yang mempengaruhi pemilihan koping, bentuk koping dan tindakan yang dilakukan sebelum dan saat terjadi permasalahan pemenuhan air bersih. Berdasarkan hasil analisis, tindakan berkaitan dengan permasalahan pemenuhan air bersih yang dilakukan oleh masyarakat Kelurahan Rowosari lebih beragam dibandingkan dengan tindakan yang dilakukan masyarakat Kampung Tambaklorok. Tindakan-tindakan tersebut meliputi tindakan teknis/struktural, ekonomis dan sosial.
\end{abstract}

Kata Kunci : Penyediaan Air Bersih, Pemenuhan Air Bersih, Mekanisme Koping

\section{ABSTRACT}

The issue of fulfilling clean water is related to the gap in providing clean water with the demand for clean water. Adaptation efforts face a lack of availability of clean water known as coping terms. Coping with pressure is one component of vulnerability. This study has a research question related to "how is the coping mechanism of the people of Kampung Tambaklorok and Rowosari Village regarding the problem of fulfilling clean water?". The purpose of this study was to examine coping mechanisms carried out by the people of Tambaklorok Village and Rowosari Village in fulfilling clean water. Tambaklorok Village and Rowosari Village are two areas in Semarang City that have problems in meeting clean water. The research approach used is the survey research method by distributing questionnaires to the public. The analysis used in the study is descriptive statistics. The findings of the study are that there are differences and similarities in the coping mechanism of the people of Tambaklorok Village and Rowosari Village. The difference in coping mechanisms is assessed based on factors that influence coping choices, forms of coping and actions taken before and when there are problems in meeting clean water. Based on the results of the analysis, actions related to the issue of fulfilling clean water carried out by Rowosari Village community are more diverse compared to the actions taken by the community of Kampung Tambaklorok. These actions include technical / structural, economic and social actions.

Keyword: Clean Water Supply, Clean Water Fulfillment, Coping Mechanism 
Putri, Setyono/ Jurnal Pembangunan Wilayah dan Kota, Vol.15, No.4, 2019, 326-339

Doi: https://doi.org/10.14710/pwk.v15i4.21639

\section{PENDAHULUAN}

Perkembangan suatu wilayah yang pesat tidak lepas dari fenomena laju pertumbuhan penduduk yang meningkat. Jumlah penduduk yang meningkat berimplikasi pada meningkatnya kebutuhan sarana dan prasarana yang ada di suatu wilayah. Prasarana kota yang paling berpengaruh terhadap perkembangan kota yaitu transportasi, air bersih dan saluran pembuangan (Kaiser, E.J. et. al, 1995). Penyediaan air bersih menjadi salah satu komponen yang penting dalam perkembangan kota dan permasalahan terkait prasarana tersebut menjadi penting untuk dikaji karena berkaitan dengan pemenuhan kebutuhan pokok masyarakat. Air bersih merupakan air yang memenuhi persyaratan bagi sistem penyediaan air minum, persyaratan tersebut meliputi kualitas air yang meliputi kualitas fisik, kimia, biologis dan radiologis sehingga apabila dikonsumsi tidak menimbulkan efek samping (Kementrian Kesehatan, 1990).

Penyediaan air bersih di Indonesia diatur berdasarkan Peraturan Pemerintah Nomor 122 Tahun 2015 tentang Sistem Penyediaan Air Minum yang dilakukan oleh Perusahaan Daerah Air Minum (PDAM). Berdasarkan data Riset Kesehatan Dasar 2013, hasil menunjukkan bahwa jenis sumber air bersih untuk seluruh kebutuhan rumah tangga di Indonesia berasal dari sumur gali terlindungi (29,2\%), PDAM (19,7\%) dan sumur pompa (24,1\%) (Morintoh et al., 2015). Permasalahan pemenuhan air bersih masih menemui kendala dalam penyediaannya. Kendala utama dalam pembangunan infrastruktur SPAM di perkotaan adalah laju pertumbuhan penduduk di perkotaan lebih besar dari peningkatan pelayanan air minum (Bappenas, 2017).

Kota Semarang merupakan salah satu kota metropolitan dengan jumlah penduduk lebih dari 1.000.000 jiwa yang mengalami permasalahan penyediaan air bersih. Kota Semarang masih mengalami beberapa permasalahan akses air bersih dan penyediaan air bersih. Kesenjangan penyediaan air melalui perpipaan PDAM dan permintaan air bersih di Kota Semarang juga menjadi salah satu masalah yang dihadapi. Partisipasi masyarakat dalam pemenuhan air bersih dibutuhkan sebagai salah satu upaya dalam menanggulangi kekurangan ketersediaan air bersih. Tingkat pelayanan air bersih melalui saluran perpipaan PDAM sebesar 59\%, memberikan peluang kepada masyarakat untuk mengeksploitasi air tanah secara berlebihan (Rezagama \& Sabar, 2015).

Karakteristik pemenuhan air bersih berbeda antara satu wilayah dengan wilayah lain terutama berkaitan dengan perbedaan kondisi geografis. Kampung Tambaklorok merupakan salah satu kampung yang berada di Kecamatan Semarang Utara dengan karakteristik daerah yang berada di dataran pesisir. Masyarakat mengandalkan pemenuhan akses terhadap air bersih melalui sumur artetis yang dikembangkan dan dikelola swadaya oleh beberapa masyarakat. Kelurahan Rowosari, Kecamatan Tembalang merupakan salah satu daerah yang juga mengalami krisis air. Wilayah tersebut memiliki karakteristik kondisi geografis perbukitan. Aliran PDAM yang masuk belum mencakup seluruh wilayah di Kelurahan Rowosari, dikarenakan pipa PDAM tidak kuat untuk mengalir ke daerah atas. Masyarakat memenuhi kebutuhan air bersih dengan memanfaatkan air dari sumur air tanah dangkal dan air sungai.

Upaya-upaya masyarakat di Kampung Tambaklorok dan Kelurahan Rowosari merupakan bentuk dari coping mechanism terhadap suatu tekanan, dalam hal ini tekanan yang dimaksud adalah permasalahan pemenuhan air bersih. Coping mechanism atau mekanisme koping adalah semua prasyarat yang memungkinkan tindakan dan penyesuaian respon terhadap perubahan eksternal pada saat ini dan masa depan yang bergantung pada faktor sosial dan biofisik (Grace et al., 2013). Kaitannya dengan permasalahan pemenuhan air bersih, koping merupakan bagian dari MPA (Manajemen Permintaan Air). Penelitian yang dilakukan oleh Nastiti et al. (2017), strategi koping terhadap air bersih juga dilakukan melalui tiga cara, di antaranya : penyimpanan air bersih, perawatan sumber air bersih, dan penggunaan sumber air bersih dari wilayah lain. Koping dalam menghadapi kelangkaan air dipengaruhi oleh ketersediaan sumber daya. Sumber daya tersebut berhubungan dengan kemampuan untuk mengadopsi rencana, strategi dan taktik yang membantu penggunaan air yang efektif dan efisien (Ashton, 2002 dalam Adeniji- Oloukoi et al., 2013). Selain itu, mekanisme koping terhadap kelangkaan air dapat didukung dengan membangun kerja sama bersama stakeholder, seperti perlibatan universitas dan organisasi melalui dengan melakukan pendekatan kerentanan dan perencanaan adaptasi (Boonsoong, B. et al. 2010). Penelitian ini membahas mekanisme 
koping di dua lokasi yang memiliki permasalahan air bersih yang berbeda karena adanya perbedaan kondisi geografis.

Kapasitas coping (koping) dan paparan merupakan bagian dari kerentanan yang menentukan tingkat kerentanan. Kemampuan wilayah dalam menanggulangi dampak negatif merupakan usaha untuk mengurangi kerentanan. Pengurangan kerentanan dilakukan dalam dua fase yaitu kesiapsiagaan dan manajemen bencana. Fase kesiapsiagaan berkaitan dengan tindakan antisipasi masyarakat sebelum terjadinya permasalahan pemenuhan air bersih. Manajemen bencana berkaitan dengan tindakan masyarakat dalam menghadapi permasalahan pemenuhan air bersih di lingkungannya. Penelitian ini akan membahas mengenai mekanisme koping masyarakat sebagai bentuk pengurangan kerentanan di Kampung Tambaklorok dan Kelurahan Rowosari, kemudian dimaksudkan untuk melihat faktor yang mempengaruhi pemilihan koping dalam permasalahan pemenuhan air bersih di kedua wilayah yang memiliki perbedaan kondisi geografis.

\section{DATA DAN METODE}

\subsection{Data}

Penelitian ini memiliki objek utama penelitian berupa rumah tangga. Lokasi penelitian berada di Kampung Tambaklorok, Kelurahan Tanjung Mas dan Kelurahan Rowosari, Kota Semarang. Justifikasi pemilihan kedua lokasi penelitian di antaranya:

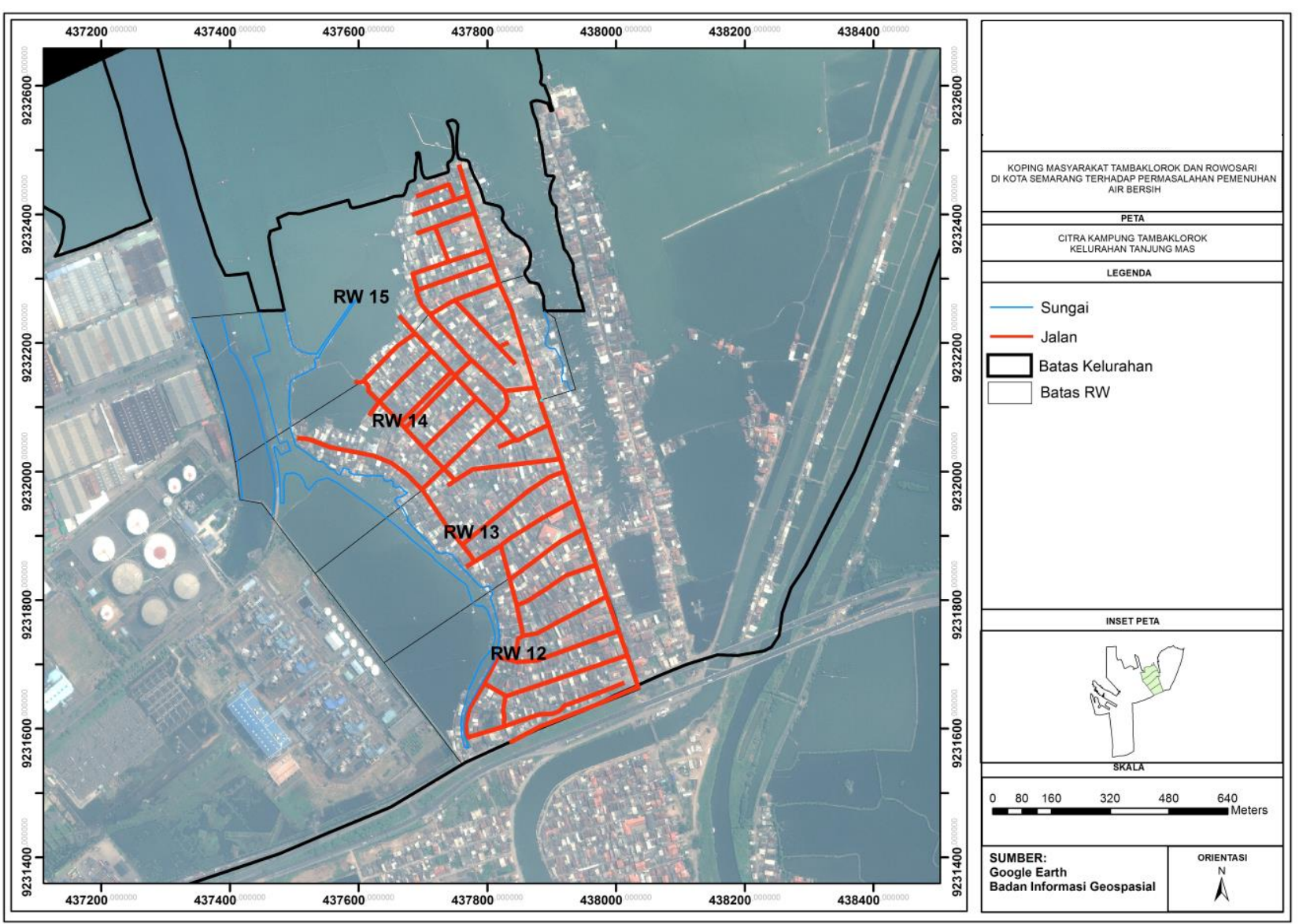

Sumber: Hasil Analisis Penulis, 2018

Gambar 1. Lokasi Penelitian Kampung Tambaklorok

a. $\quad$ Kampung Tambaklorok merupakan daerah yang berada di Kelurahan Tanjung Mas, Kecamatan Semarang Utara yang mengalami permasalahan air bersih. Hampir seluruh sumur masyarakat 
berair payau dan asin karena adanya intrusi air laut (Alihar, 2018). Gambar 1 menujukkan lokasi penelitian Kampung Tambaklorok.

b. Sebagian besar wilayah Semarang bagian hulu yang tidak tersentuh layanan PDAM menghadapi krisis air bersih dikarenakan musim kemarau yang berkepanjangan yaitu di antaranya Kecamatan Gunung Pati, Tembalang, dan Mijen (Alihar, 2018). Kelurahan Rowosari merupakan salah satu daerah di Kota Semarang yang mengalami kesulitan dalam pemenuhan air bersih. Kelurahan Rowosari memiliki kondisi geografis perbukitan sehingga jaringan PDAM belum mampu naik ke daerah tersebut. Gambar 2 menujukkan lokasi penelitian Kelurahan Rowosari.

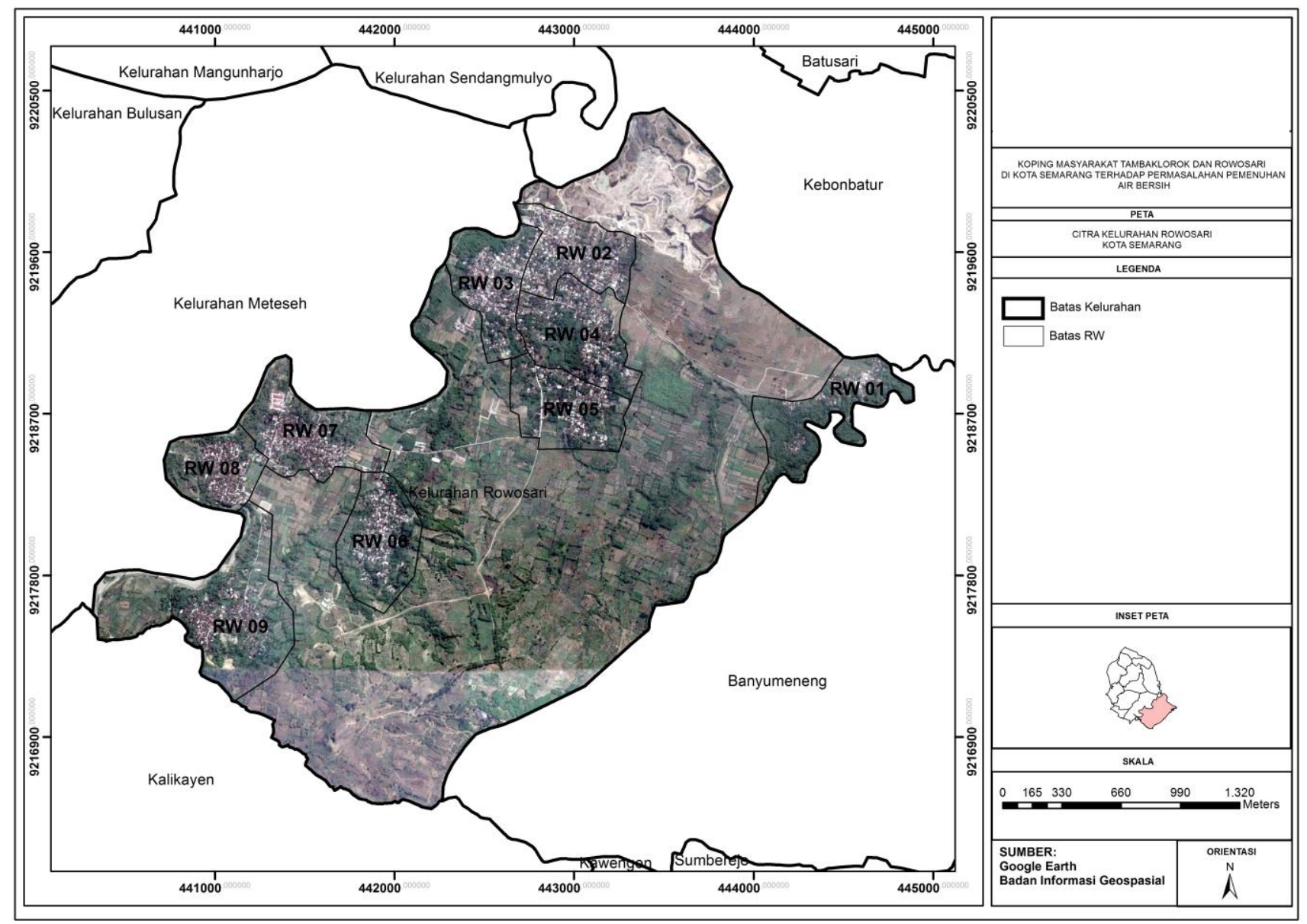

Sumber: Hasil Analisis Penulis, 2018

Gambar 2. Lokasi Penelitian Kelurahan Rowosari

Pendekatan penelitian yang digunakan yaitu metode penelitian survei. Pengambilan sampling pada penelitian ini menggunakan probability sampling. Metode pengambilan sampel dalam penelitian ini menggunakan pengambilan sampel acak sederhana (simple random sampling). Metode pengambilan sampel acak sederhana ialah sebuah sampel yang diambil sedemikian rupa sehingga tiap unit penelitian atau satuan elementer dari populasi mempunyai kesempatan yang sama (Singarimbun dan Effendi, 1989). Populasi sampling dalam penelitian ini adalah seluruh rumah tangga yang ada di Kampung Tambaklorok dan Kelurahan Rowosari. Menurut data BPS Kota Semarang Tahun 2017 dan data NUSP Tahun 2017, jumlah KK di Kampung Tambaklorok sebesar 2.032 KK dan Kelurahan Rowosari berjumlah 3.112 KK. Sampel yang dibutuhkan dalam penelitian ini berjumlah 68 jiwa. Penentuan jumlah sampel di masing-masing lokasi penelitian ialah 27 KK di Kampung Tambaklorok dan 41 KK di Kelurahan Rowosari. 


\subsection{Analisis}

Analisis yang digunakan dalam penelitian adalah analisis statistik deskriptif. Penelitian dilakukan dengan mengumpulkan informasi terkait koping masyarakat terhadap permasalahan pemenuhan air bersih di lokasi penelitian. Kemudian menganalisis informasi tersebut dan menjelaskan mengenai koping masyarakat di dua lokasi penelitian. Analisis statistik deskriptif adalah suatu alat statistik yang berkenaan dengan bagaimana cara mendeskripsikan, menggambarkan, menjabarkan atau menguraikan data sehingga mudah dipahami. Fungsi analisis deskriptif adalah untuk memberikan gambaran umum tentang data yang telah diperoleh, gambaran umum ini bisa menjadi acuan untuk melihat karakteristik data yang kita peroleh tanpa melihat hubungan antar karakteristik-karakteristik tersebut..

Penelitian ini membahas mengenai upaya pemenuhan air bersih. Kesenjangan antara permintaan dan penyediaan air bersih mengakibatkan adanya upaya masyarakat untuk memenuhi kebutuhan terhadap air bersih. Terbatasnya cakupan pelayanan air bersih publik menuntut adanya peran partisipasi masyarakat sesuai dengan kondisi serta kemampuan mereka sendiri (Apriyana, 2010). Penelitian yang dilakukan oleh Nastiti et al. (2017), strategi koping terhadap air bersih juga dilakukan melalui tiga cara, di antaranya : penyimpanan air bersih, perawatan sumber air bersih, dan penggunaan sumber air bersih dari wilayah lain. Upaya-upaya masyarakat tersebut, merupakan salah satu bentuk coping mechanism (mekanisme koping) terhadap pemenuhan air bersih.Analisis dilakukan melalui penilaian skala likert 1-10. Analisis yang digunakan dalam penelitian ini meliputi analisis faktor pemilihan koping, bentuk koping dan mekanisme koping. Teori yang digunakan dalam analisis dapat dilihat pada Tabel 1.

Tabel 1. Teori Analisis Koping Masyarakat

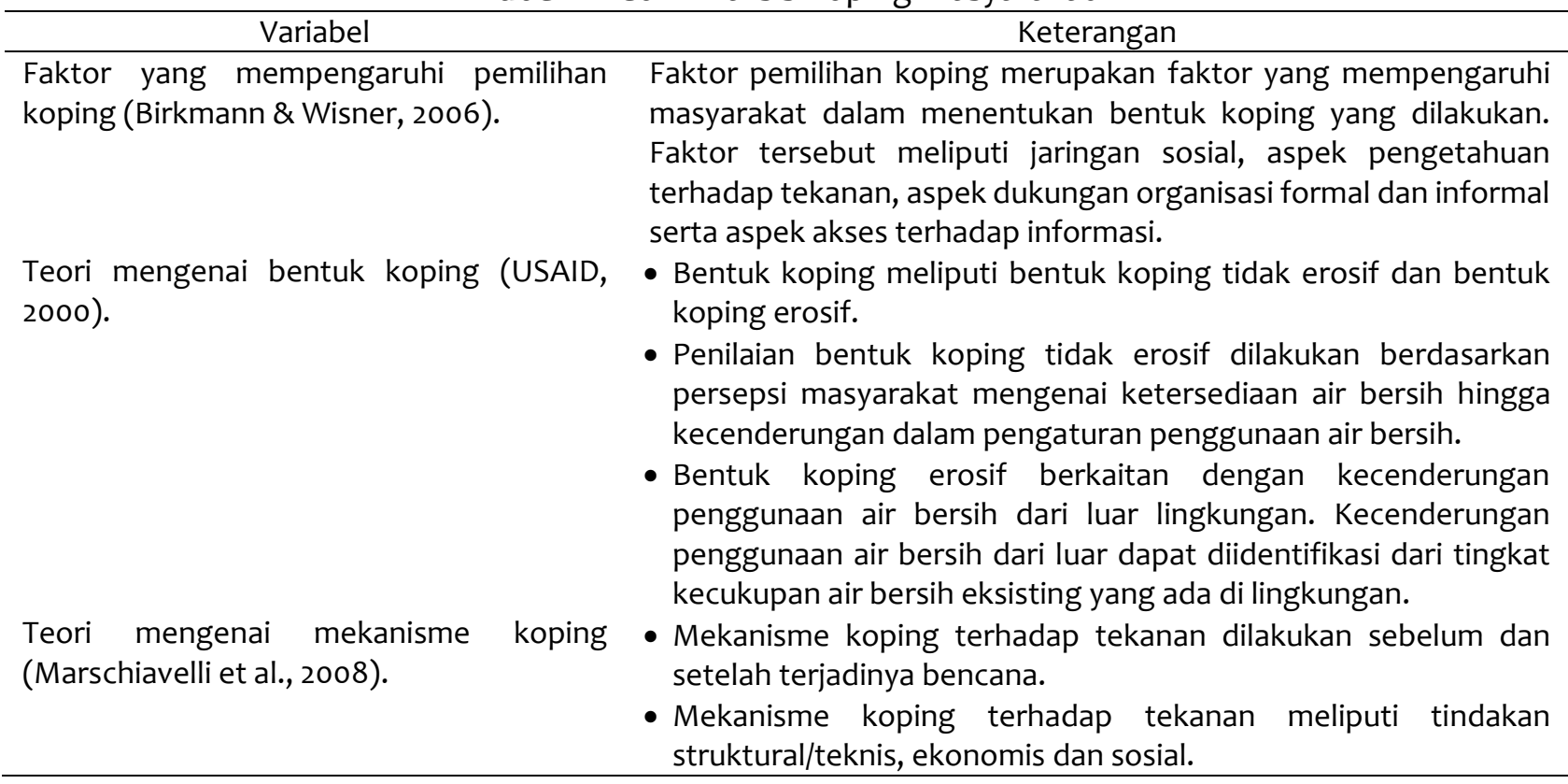

Sumber: Hasil analisis, 2018

\section{HASIL DAN PEMBAHASAN}

\subsection{Faktor Pemilihan Koping}

Faktor pemilihan koping masyarakat terhadap permasalahan pemenuhan air bersih dipengaruhi oleh jaringan sosial, pengetahuan terhadap tekanan, dukungan organisasi formal dan informal, serta akses terhadap informasi. Penilaian dilakukan menggunakan skala likert 1-10. Hasil rata-rata skor pada variabel faktor pemilihan koping dapat dilihat pada Gambar 1. Gambar 1 mendeskripsikan penilaian terhadap jaringan 
sosial di Kelurahan Rowosari dan Kampung Tambaklorok dilihat berdasarkan peran dalam organisasi, kerukunan masyarakat serta akses terhadap institusi. Peran dalam organisasi memiliki rata-rata skor 7 untuk Kampung Tambaklorok dan 6 untuk Kelurahan Rowosari. Hasil skor rata-rata tersebut memiliki arti bahwa peran dalam organisasi rata-rata masyarakat di Kampung Tambaklorok memiliki nilai yang positif (peran individu dalam organisasi masuk ke dalam kategori cukup berperan) dan Kelurahan Rowosari memiliki nilai yang negatif (peran individu dalam organisasi masuk ke dalam kategori kurang berperan). Penilaian terhadap kerukunan masyarakat memiliki nilai rata-rata 9 untuk Kampung Tambaklorok dan Kelurahan Rowosari. Penilaian frekuensi pertemuan warga memiliki rata-rata skor sebesar 9 untuk Kampung Tambaklorok dan 8 untuk Kelurahan Rowosari. Berdasarkan data tersebut, kerukunan antar masyarakat di Kampung Tambaklorok dan Kelurahan Rowosari termasuk ke dalam kategori positif (kerukunan antar masyarakat tinggi).

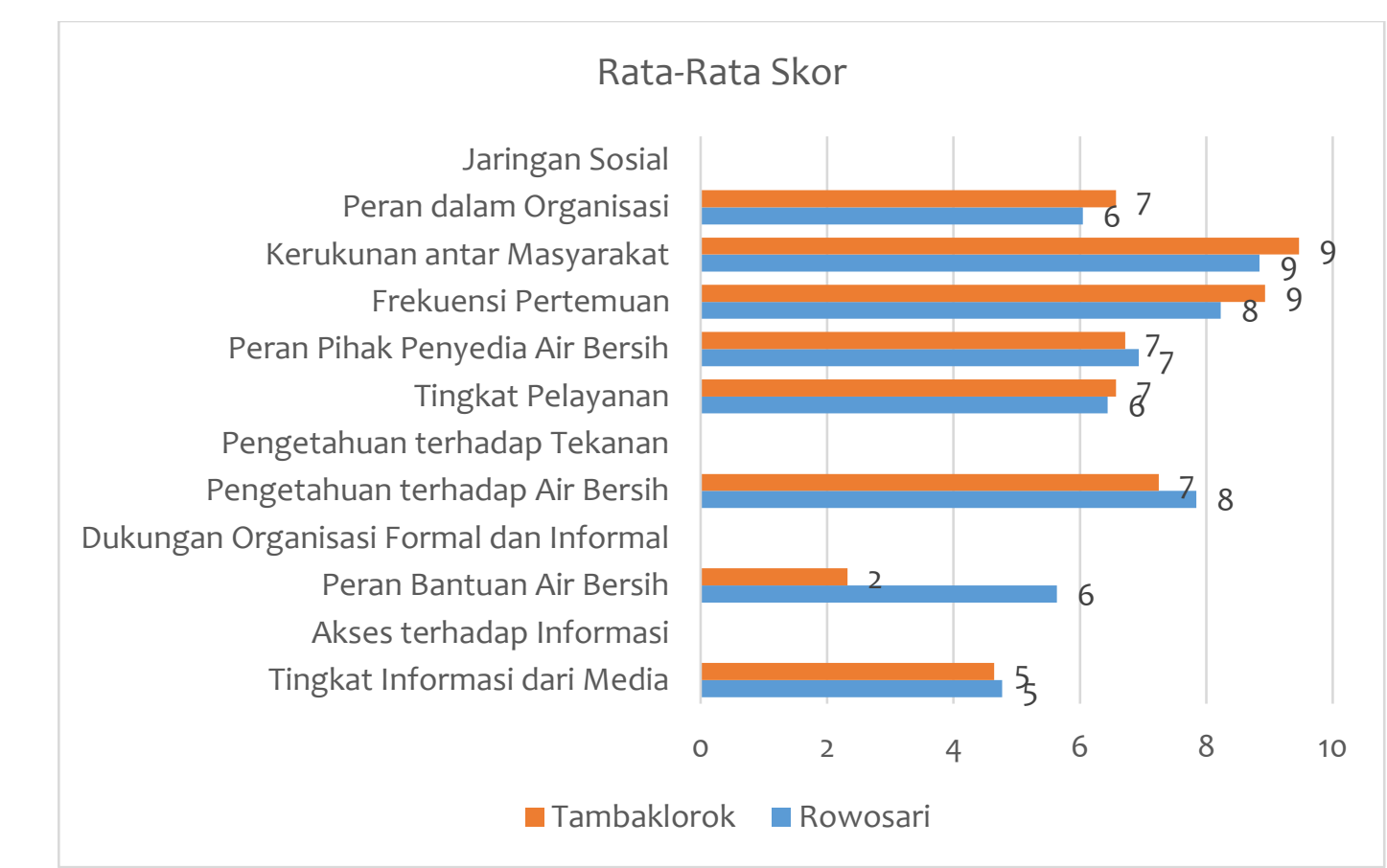

Sumber: Hasil Analisis, 2018

Gambar 1. Rerata Skor Faktor Pemilihan Koping

Peran pihak penyedia air bersih berdasarkan persepsi masyarakat memiliki nilai rata-rata 7 untuk Kampung Tambaklorok dan Kelurahan Rowosari. Hasil tersebut menggambarkan bahwa peran pihak penyedia air bersih memiliki nilai positif (perannya cukup dirasakan oleh masyarakat). Selain itu, didukung dengan hasil penilaian tingkat pelayanan terkait air bersih yang dirasakan masyarakat cukup baik dengan nilai rata-rata 7 untuk Kampung Tambaklorok dan 6 untuk Kelurahan Rowosari. Berkaitan dengan pengetahuan terhadap air bersih, masyarakat Kampung Tambaklorok dan Kelurahan Rowosari memiliki pengetahuan yang cukup baik (dengan skor 8 untuk Kelurahan Rowosari dan skor 7 untuk Kampung Tambaklorok). Masyarakat mengetahui hampir seluruh syarat (dua dari tiga syarat) air bersih yang layak.

Penilaian terhadap peran bantuan air bersih oleh organisasi formal dan informal bagi masyarakat Kampung Tambaklorok memiliki skor 2 (masuk kategori sangat negatif). Berdasarkan data tersebut, peran bantuan air bersih tidak dirasakan oleh masyarakat Kampung Tambaklorok. Peran bantuan air bersih pada saat terjadi kekurangan air bersih bagi masyarakat Kelurahan Rowosari memiliki skor 6, masuk ke kategori negatif (peran bantuan air bersih kurang berperan dalam memenuhi kebutuhan air bersih saat terjadi kekurangan air bersih). Faktor pemilihan koping selanjutnya berkaitan dengan akses terhadap informasi. 
Penilaian penyerapan informasi melalui media informasi yang dimiliki oleh masyarakat, memiliki skor 5 untuk Kampung Tambaklorok dan Kelurahan Rowosari. Kondisi tersebut menggambarkan tingkat penyerapan informasi air bersih melalui media informasi kecil (masuk ke dalam kategori negatif).

3.2 Bentuk Koping Masyarakat

Koping merupakan kemampuan untuk menangani tekanan yang sulit secara efektif (The Second Edition of New Oxford, 2005 dalam Aldwin, 2007). Kaitannya dengan koping terhadap permasalahan pemenuhan air bersih dapat dibagi menjadi tiga bagian yaitu koping tidak erosif (mengandalkan sumber daya yang ada), koping bersifat erosif (penggunaan sumber daya di luar lingkungan) dan migrasi keluar. Pada penelitian ini, bentuk koping ketiga tidak diterapkan dikarenakan lokasi penelitian memiliki perbedaan kondisi sosial yang dapat mengurangi kemungkinan adanya migrasi keluar akibat permasalahan air bersih.

Koping yang erosif merupakan bentuk koping dengan memanfaatkan sumber daya yang dimiliki. Bentuk koping ini melibatkan pola konsumsi/pola penggunaan sumber air bersih yang digunakan. Hal yang berkaitan di antaranya pengaturan penggunaan air bersih. Bentuk koping yang erosif dilakukan apabila bentuk koping pertama tidak dapat digunakan dalam menghadapi tekanan. Penggunaan sumber daya di luar lingkungan merupakan bentuk koping erosif. Apabila pengaturan penggunaan air bersih tidak dapat mengatasi permasalahan air bersih, pengambilan sumber air di luar lingkungan menjadi pilihan. Pengamatan sumber air bersih di lingkungan digunakan untuk mengetahui sumber air bersih yang digunakan oleh masyarakat setempat. Berdasarkan data lapangan, sumber air bersih yang digunakan oleh masyarakat berupa artetis, PDAM, sumur gali terlindungi, dan sumur gali pompa. Gambar 2 mendeskripsikan sumber air bersih yang digunakan oleh masyarakat di Kelurahan Rowosari dan Kampung Tambaklorok.

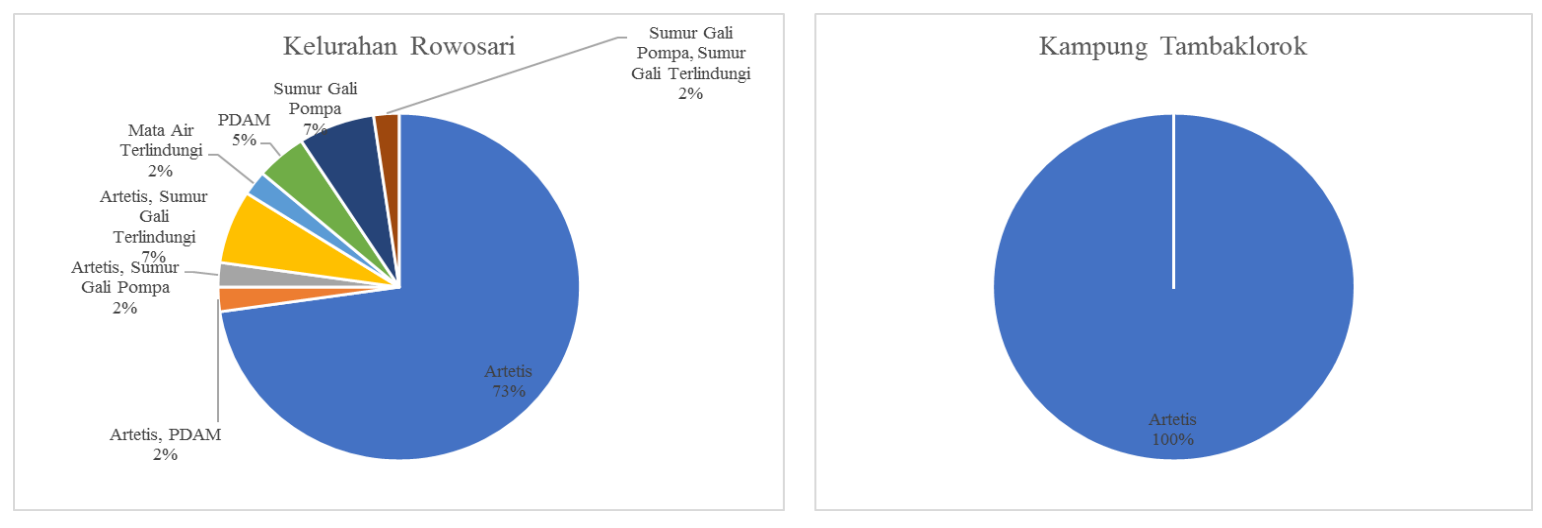

Sumber: Hasil Analisis, 2018

Gambar 2. Sumber Air Bersih Masyarakat

Penilaian terhadap bentuk koping masyarakat terhadap permasalahan pemenuhan air bersih dilakukan menggunakan skala likert dengan skala rating 1-10. Berdasarkan hasil analisis data lapangan, ditemukan rerata skor pada tiap variabel bentuk koping masyarakat terhadap permasalahan pemenuhan air bersih di dua lokasi penelitian. Hasil rata-rata skor pada variabel bentuk koping dapat dilihat pada Gambar 3 . Berdasarkan hasil analisis, bentuk koping tidak erosif yang dilihat berdasarkan kecenderungan pengaturan air bersih memiliki skor 5 untuk Kampung Tambaklorok dan Kelurahan Rowosari. Skor tersebut termasuk ke dalam kategori negatif (tingkat kecenderungan pengaturan air bersih masyarakat kecil). Bentuk koping erosif digambarkan melalui kecukupan sumber air bersih yang memiliki skor 9 untuk Kampung Tambaklorok dan Kelurahan Rowosari. Skor tersebut masuk ke dalam kategori positif (kecukupan air bersih tinggi di dua lokasi penelitian). 
Putri, Setyono/ Jurnal Pembangunan Wilayah dan Kota, Vol.15, No.4, 2019, 326-339

Doi: https://doi.org/10.14710/pwk.v15i4.21639

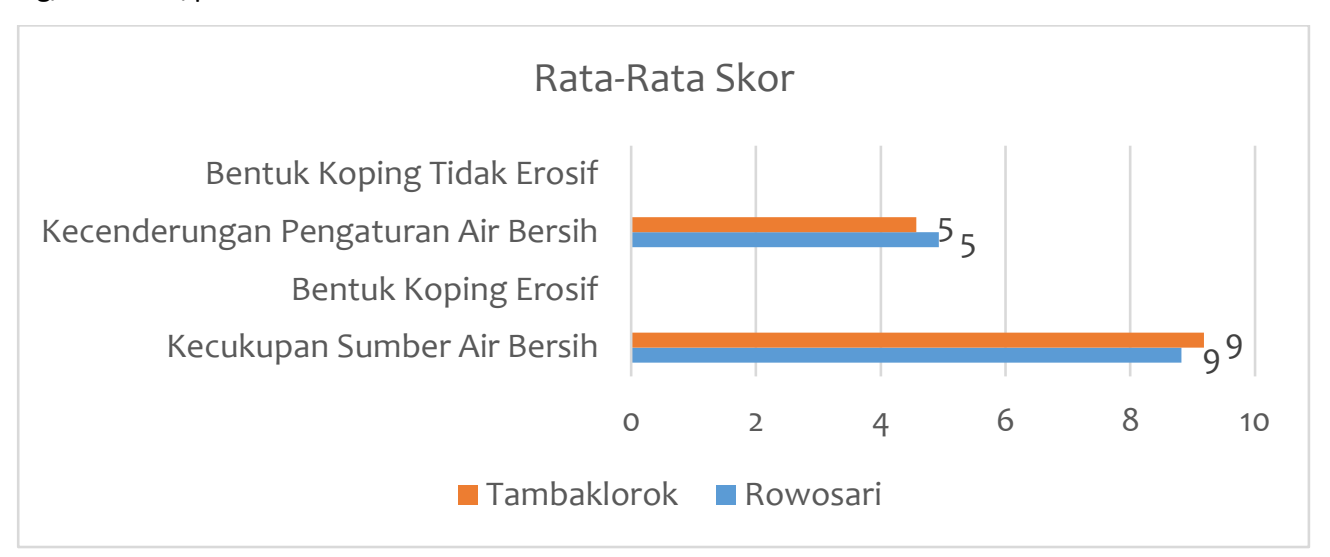

Sumber: Hasil Analisis, 2018

Gambar 3. Rerata Skor Bentuk Koping

\subsection{Mekanisme Koping}

Mekanisme koping masyarakat dijabarkan dalam kegiatan antisipasi permasalahan pemenuhan air bersih dan tindakan saat terjadi permasalahan pemenuhan air bersih. Setiap fase dalam mekanisme koping akan dijabarkan berdasarkan jenis tindakan yang dilakukan di antaranya: tindakan teknis, tindakan ekonomis, dan tindakan sosial. Tindakan teknis merupakan tindakan yang berkaitan dengan infrastruktur air bersih. Tindakan ekonomis berkaitan dengan pengoptimalan sumber daya yang dimiliki. Tindakan sosial berkaitan dengan tindakan yang melibatkan masyarakat. Tindakan yang dilakukan oleh masyarakat Kampung Tambaklorok dalam antisipasi permasalahan pemenuhan air bersih dapat dilihat pada Tabel 2.

Tabel 2. Koping Antisipasi Permasalahan Pemenuhan Air Bersih Tambaklorok

\begin{tabular}{lcc}
\hline \multicolumn{1}{c}{ Strategi yang Digunakan } & Responden & Persentase \\
\hline Tindakan Teknis & 28 & $100 \%$ \\
Tidak ada tindakan & & \\
Tindakan Ekonomis & 24 & $85,71 \%$ \\
Tindakan ada tindakan & 4 & $14,29 \%$ \\
Menampung Air di Bak & & $100 \%$ \\
Tindakan Sosial & 28 & \\
Tidak ada tindakan & & \\
\hline
\end{tabular}

Sumber: Hasil Analisis, 2018

Pada Tabel 2 diketahui bahwa tidak terdapat tindakan teknis yang dilakukan oleh masyarakat Kampung Tambaklorok dalam antisipasi permasalahan pemenuhan air bersih. Sebanyak $14,29 \%$ masyarakat Kampung Tambaklorok melakukan tindakan ekonomis berupa menampung air di bak atau tempat penampungan air sebagai antisipasi kurangnya air bersih. Belum ditemukan adanya tindakan sosial yang dilakukan bersama-sama di lingkungan masyarakat untuk melakukan tindakan antisipasi permasalahan pemenuhan air bersih. Berdasarkan kondisi tersebut, dapat disimpulkan bahwa masyarakat Kampung Tambaklorok belum melakukan tindakan antisipasi permasalahan pemenuhan air bersih. Tabel 3 mendeskripsikan tindakan yang dilakukan oleh masyarakat Kampung Tambaklorok saat terjadi permasalahan pemenuhan air bersih. 
Putri, Setyono/ Jurnal Pembangunan Wilayah dan Kota, Vol.15, No.4, 2019, 326-339

Doi: https://doi.org/10.14710/pwk.v15i4.21639

Tabel 3. Koping Saat Terjadi Permasalahan Pemenuhan Air Bersih Tambaklorok

\begin{tabular}{lrr}
\hline \multicolumn{1}{c}{ Strategi yang Digunakan } & Responden & Persentase \\
\hline Tindakan Teknis & 28 & $100 \%$ \\
Tidak ada tindakan & & \\
Tindakan Ekonomis & 27 & $96,43 \%$ \\
Tindakan ada tindakan & 1 & $3,57 \%$ \\
Membeli air dari sumber lain (galon atau tangki & & \\
air) & 28 & $100 \%$ \\
Tindakan Sosial & 28 \\
Tidak ada tindakan & & \\
\hline
\end{tabular}

Sumber: Hasil Analisis, 2018

Pada Tabel 3 diketahui bahwa tidak terdapat tindakan teknis yang dilakukan oleh masyarakat Kampung Tambaklorok saat terjadi permasalahan pemenuhan air bersih. Tindakan ekonomis yang dilakukan oleh masyarakat Kampung Tambaklorok berkaitan dengan permasalahan pemenuhan air bersih yaitu membeli air dari sumber air di luar lingkungan. Sebanyak 96,43\% masyarakat Kampung Tambaklorok tidak melakukan tindakan ekonomis. Belum ditemukan adanya tindakan sosial yang dilakukan bersama-sama di lingkungan masyarakat saat terjadi permasalahan pemenuhan air bersih. Berdasarkan kondisi tersebut, dapat disimpulkan bahwa masyarakat Kampung Tambaklorok tidak melakukan koping saat terjadi permasalahan air bersih. Tindakan yang dilakukan oleh masyarakat Kelurahan Rowosari dalam antisipasi permasalahan pemenuhan air bersih dapat dilihat pada Tabel 4.

Tabel 4. Koping Antisipasi Permasalahan Pemenuhan Air Bersih Kelurahan Rowosari

\begin{tabular}{lcr}
\hline \multicolumn{1}{c}{ Strategi yang Digunakan } & Responden & Persentase \\
\hline Tindakan Teknis & 34 & $75,56 \%$ \\
Tidak ada tindakan & 4 & $8,89 \%$ \\
Memeriksa tandon & 3 & $6,67 \%$ \\
Mengecek sumber air & 2 & $4,44 \%$ \\
Mengecek pompa & 1 & $2,22 \%$ \\
Ambil air dari sungai & 1 & $2,22 \%$ \\
Pembersihan Sumur & & \\
Tindakan Ekonomis & 34 & $75,56 \%$ \\
Tidak ada tindakan & 3 & $6,67 \%$ \\
Menghemat air & 3 & $6,67 \%$ \\
Menampung air & 2 & $4,44 \%$ \\
Mengatur pemakaian & 2 & $4,44 \%$ \\
Melakukan pergiliran pemakaian & 1 & $2,22 \%$ \\
Membeli air & & \\
Tindakan Sosial & 41 & $91,11 \%$ \\
Tidak ada tindakan & 2 & $4,44 \%$ \\
Melakukan pengaduan & 1 & $2,22 \%$ \\
Membuat saluran air secara gotong royong & 1 & $2,22 \%$ \\
Memperbaiki sendang & &
\end{tabular}

Sumber: Hasil Analisis, 2018

Berdasarkan Tabel 4, tindakan teknis yang dilakukan oleh masyarakat Kelurahan Rowosari sebagai tindakan antisipasi permasalahan pemenuhan air bersih di antaranya pemeriksaan tandon, pengecekan 
sumber air bersih, pengecekan pompa, pengambilan air dari sungai dan pembersihan sumur. Pemeriksaan dilakukan oleh petugas pengelola sumur artetis yang dibentuk oleh masyarakat setempat. Meskipun demikian, masih terdapat 75,56\% masyarakat Kelurahan Rowosari tidak melakukan tindakan teknis terkait permasalahan pemenuhan air bersih. Sebanyak $24,44 \%$ masyarakat Kelurahan Rowosari melakukan beberapa tindakan ekonomis dalam antisipasi permasalahan pemenuhan air bersih, di antaranya penghematan air, pengaturan penggunaan air bersih, pergiliran pemakaian serta pembelian air bersih dari luar lingkungan.

Berkaitan dengan tindakan sosial terhadap pemenuhan air bersih, sebagian besar masyarakat Kelurahan Rowosari yaitu sebanyak 91,11\% tidak melakukan tindakan sosial terkait permasalahan pemenuhan air bersih. Hanya sebagian kecil yang melakukan tindakan sosial berkaitan dengan koping saat terjadi permasalahan pemenuhan air bersih. Tindakan sosial yang dilakukan oleh masyarakat Kelurahan Rowosari sebagai antisipasi permasalahan pemenuhan air bersih di antaranya pengaduan permasalahan air pada instansi terkait, pembuatan saluran air bersih secara gotong royong dan perbaikan sendang secara bersamasama. Pengaduan yang dilakukan oleh masyarakat mengenai permasalahan air bersih disampaikan melalui RT/RW setempat dengan tujuan dapat ditanggulangi oleh instansi yang bertanggung jawab terhadap pemenuhan air bersih. Tabel 5 mendeskripsikan koping saat terjadi permasalahan pemenuhan air bersih di Kelurahan Rowosari.

Tabel 5. Koping Saat TerjadiPermasalahan Pemenuhan Air Bersih Kelurahan Rowosari

\begin{tabular}{lrr}
\hline \multicolumn{1}{c}{ Strategi yang Digunakan } & Responden & Persentase \\
\hline Tindakan Teknis & 43 & \\
Tidak ada tindakan & 1 & $95,56 \%$ \\
Mengecek pipa/saluran air & 1 & $2,22 \%$ \\
Mengecek tandon & & $2,22 \%$ \\
Tindakan Ekonomis & 34 & \\
Tidak ada tindakan & 2 & $80,00 \%$ \\
Mengambil air dari sungai & 2 & $4,44 \%$ \\
Mengambil air dari sumur & 2 & $4,44 \%$ \\
Memakai air PDAM & 1 & $4,44 \%$ \\
Menghemat air & 1 & $2,22 \%$ \\
Menampung air & 1 & $2,22 \%$ \\
Membeli air kemasan & & $2,22 \%$ \\
Tindakan Sosial & 43 & $95,56 \%$ \\
Tidak ada tindakan & 2 & $4,44 \%$ \\
Mengambil air dari tetangga & &
\end{tabular}

Tabel 5 menjabarkan tindakan yang dilakukan masyarakat Kelurahan Rowosari saat terjadi permasalahan pemenuhan air bersih. Pada Tabel 5, dapat diidentifikasi masyarakat akan mengecek tandon air dan pipa/saluran air apabila terjadi kemacetan aliran air bersih. Namun, sebanyak $95,56 \%$ masyarakat Kelurahan Rowosari tidak melakukan tindakan teknis saat terjadi permasalahan pemenuhan air bersih. Tindakan ekonomis yang dilakukan oleh masyarakat saat terjadi permasalahan pemenuhan air bersih di antaranya mengambil air dari berbagai sumber seperti sungai, dari sumber air bersih cadangan (bagi masyarakat yang memiliki lebih dari satu sumber air bersih), meminta air dari tetangga terdekat hingga membeli air kermasan. Tindakan sosial yang ditemukan berupa meminta air bersih dari tetangga yang memiliki ketersediaan air bersih lebih banyak.

Temuan penelitian membahas mengenai hasil temuan analisis mekanisme koping masyarakat yang terjadi di Kampung Tambaklorok dan Kelurahan Rowosari. Pembahasan dilakukan berdasarkan hasil temuan 
penelitian dari faktor pemilihan koping, bentuk koping dan mekanisme koping di dua lokasi penelitian. Mekanisme koping masyarakat terhadap permasalahan pemenuhan air bersih dibahas berdasarkan fase kesiapsiagaan dan saat terjadi bencana. Berdasarkan hasil analisis, diketahui bahwa masyarakat Kampung Tambaklorok tidak melakukan banyak tindakan yang berkaitan dengan tindakan kesiapsiagaan terhadap permasalahan pemenuhan air bersih. Sebagai antisipasi terjadinya permasalahan pemenuhan air bersih, masyarakat menampung air di bak penampung. Berkaitan dengan tindakan yang dilakukan saat terjadi permasalahan pemenuhan air bersih, yaitu mengambil air bersih dari sumber lain. Gambar 4 mendeskripsikan mekanisme koping masyarakat Kampung Tambaklorok terhadap permasalahan pemenuhan air bersih.

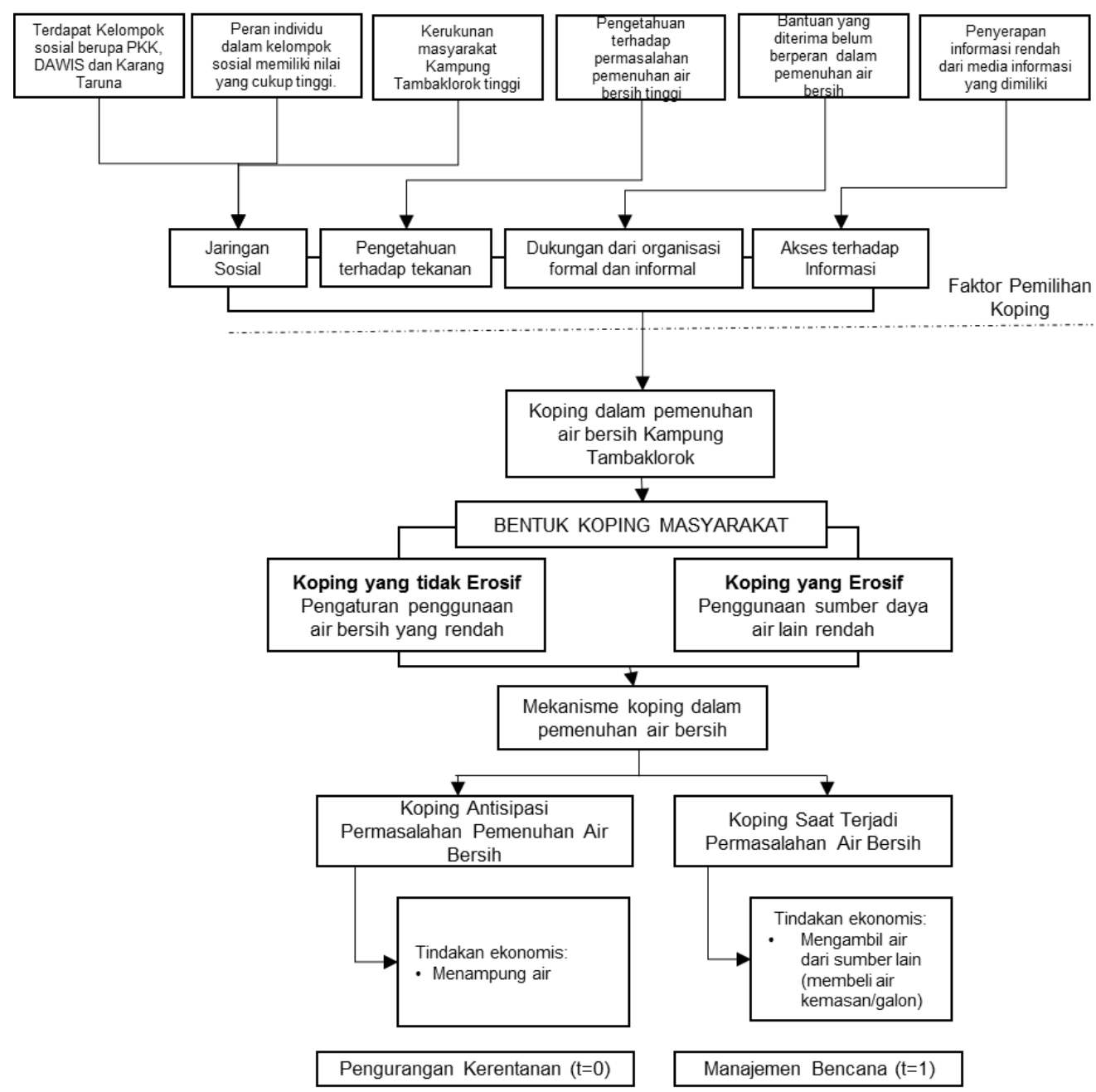

Sumber: Hasil Analisis, 2018

Gambar 4. Mekanisme Koping Masyarakat Kampung Tambaklorok terhadap Permasalahan Pemenuhan Air Bersih

Tindakan teknis yang dilakukan oleh masyarakat Kelurahan Rowosari sebagai tindakan antisipasi permasalahan pemenuhan air bersih di antaranya pemeriksaan tandon, pengecekan sumber air bersih, pengecekan pompa, pengambilan air dari sungai dan pembersihan sumur. Sebanyak $24,44 \%$ masyarakat Kelurahan Rowosari melakukan beberapa tindakan ekonomis dalam antisipasi permasalahan pemenuhan air bersih, di antaranya penghematan air, pengaturan penggunaan air bersih, pergiliran pemakaian serta pembelian air bersih dari luar lingkungan. 
Tindakan sosial yang dilakukan oleh masyarakat Kelurahan Rowosari sebagai antisipasi permasalahan pemenuhan air bersih di antaranya pengaduan permasalahan air pada instansi terkait, pembuatan saluran air bersih secara gotong royong dan perbaikan sendang secara bersama-sama. Pada saat terjadi permasalahan pemenuhan air bersih sebagai tindakan teknis, masyarakat akan mengecek tandon air dan pipa/saluran air apabila terjadi kemacetan aliran air bersih. Tindakan ekonomis yang dilakukan oleh masyarakat saat terjadi permasalahan pemenuhan air bersih di antaranya mengambil air dari berbagai sumber seperti sungai, dari sumber air bersih cadangan (bagi masyarakat yang memiliki lebih dari satu sumber air bersih) hingga membeli air kermasan. Pembahasan mekanisme koping masyarakat Kelurahan Rowosari dapat dilihat pada Gambar 5.

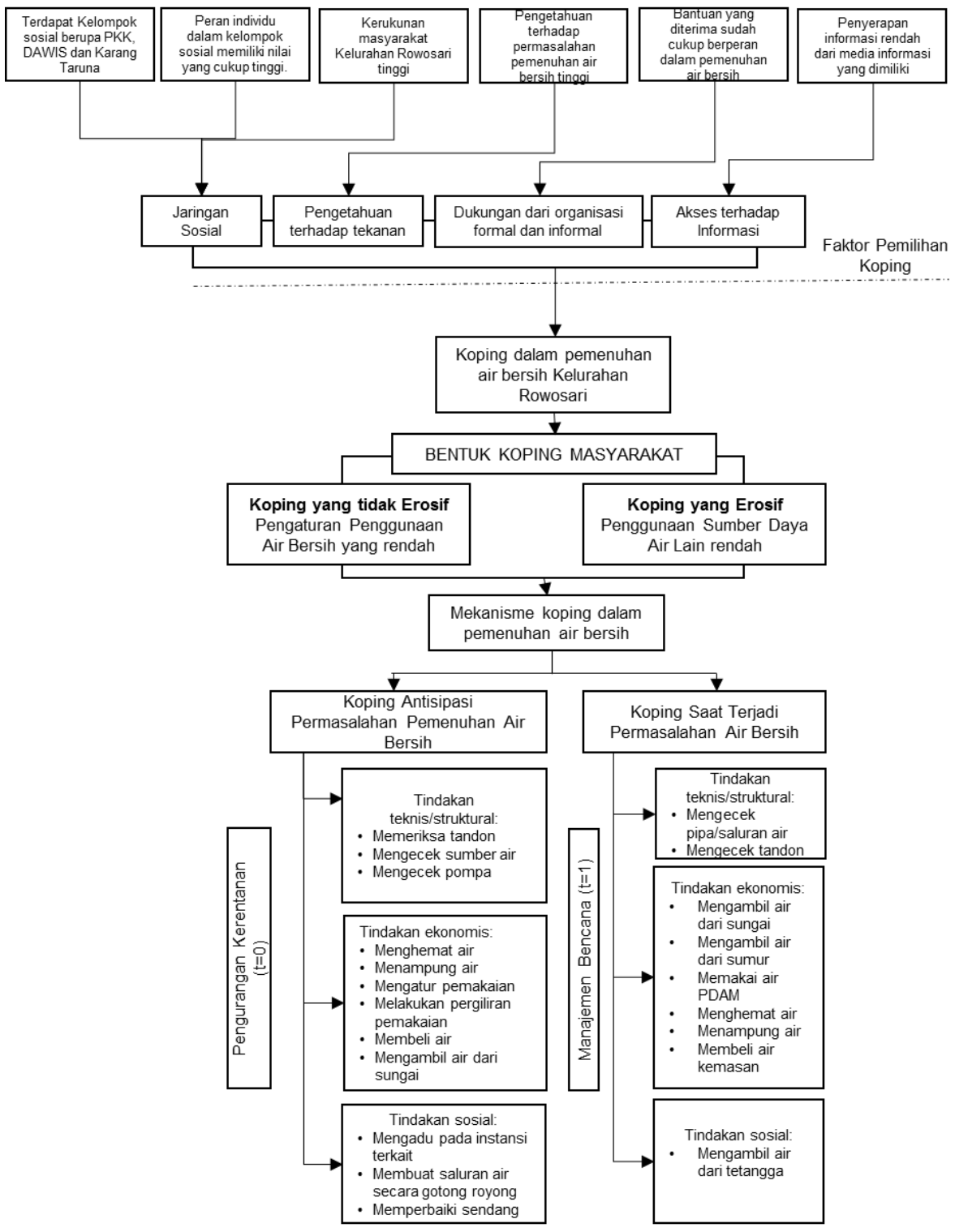

Sumber: Hasil Analisis, 2018

Gambar 5. Mekanisme Koping Masyarakat Kampung Tambaklorok Terhadap Permasalahan Pemenuhan Air Bersih 


\section{KESIMPULAN}

Permasalahan pemenuhan air bersih di Kota Semarang akibat kurangnya ketersediaan air bersih melalui jaringan PDAM, memunculkan berbagai upaya yang dilakukan oleh masyarakat untuk mengatasi permasalahan tersebut. Upaya yang dilakukan termasuk ke dalam salah satu komponen kerentanan yaitu mekanisme koping. Mekanisme koping masyarakat Kelurahan Rowosari terhadap permasalahan pemenuhan air bersih memiliki tindakan yang lebih beragam berkaitan dengan tindakan antisipasi dan tindakan saat terjadinya kekurangan air bersih. Penilaian faktor pemilihan koping dari aspek jaringan sosial di dua lokasi penelitian menggambarkan adanya kesamaan kondisi sosial masyarakat di Kampung Tambaklorok dan Kelurahan Rowosari didasarkan pada kesamaan karakteristik penduduk yang memiliki tingkat kekeluargaan yang tinggi. Perbedaan penilaian akses terhadap institusi di Kampung Tambaklorok dan Kelurahan Rowosari dapat disebabkan karena adanya perbedaan frekuensi masyarakat berhubungan dengan pihak penyedia air bersih. Belum adanya pemanfaatan media informasi sebagai media untuk menambah wawasan air bersih. Perbedaan manfaat bantuan air bersih di dua lokasi penelitian didasarkan pada banyaknya jenis bantuan air bersih yang diterima dan tingkat urgensi permasalahan air bersih di masing-masing daerah. Berkaitan dengan bentuk koping, masyarakat di Kampung Tambaklorok dan Kelurahan Rowosari memiliki kecenderungan pengaturan penggunaan air bersih masih rendah; serta kecenderungan penggunaan sumber air bersih dari luar lingkungan oleh masyarakat Kampung Tambaklorok dan Kelurahan Rowosari masih rendah.

\section{REFERENSI}

Aldwin, C. (2007). Stress, Coping, and Development: An Integrative Perspective. Second Edition. London: The Guilford Press.

Alihar, F. (2018). "Penduduk dan Akses Air Bersih di Kota Semarang ( Population and Access to Clean Water in Semarang City )." Kependudukan Indonesia. Vol. 13, hal. 67-76.

Apriyana, P. (2010). "Evaluasi Kinerja Pelananan Air Bersih Komunal di Wilayah Pengembangan Ujung Beruang Kota Bandung.” Jurnal Wilayah Dan Perencanaan Kota. Vol. 21, hal. 95-110.

Birkmann, J. dan Wisner, B.. (2006). Measuring the Un-Measurable The Challenge of Vulnerability. Germany: UNU-EHS.

Boonsoong, B. et al. (2010). "An implementation plan for using biological indicators to improve assessment of water quality in Thailand". Environ Monit Assess. Vol. 165, pp. 205-215.

Grace, A. et al.(2013). "Households' Coping Strategies for Climate Variability Related Water Shortages in Oke-Ogun Region, Nigeria." Environmental Development. Vol.5, pp. 23-38.

Kaisar, E.J. et al. (1995). Urban Land Use Planning. Fourth Edition. London: University of Illionis Press.

Marschiavelli, Mone lye Cornelia. 2008. "Vulnerability Assessment and Coping Mechanism Related to Floods in Urban Areas: A Community-Based Case Study in Kampung Melayu, Indonesia." Geo-Information for Spatial Planning and Risk Management, Faculty of Geography, Gajah Mada Univeristy. Jogjakarta.

Morintoh, P. et al, (2015). "Analisis Perbedaan Uji Kualitas Air Sumur di Daerah Dataran Tinggi Kota Tomohon dan Dataran Rendah Kota Manado Berdasarkan Parameter Fisika." Jurnal E-Biomedik (eBm). Vol. 3.

Nastiti, A. et. al. (2017). "Coping with Poor Water Supply in Peri-Urban Bandung, Indonesia: Towards a Framework for Understanding Risks and Aversion Behaviours." Environment and Urbanization. Vol. 29, pp. 69-88.

Percepatan Pembangunan Infrastruktur Air Bersih. (2017). Badan Perencanaan Pembangunan Nasional. Jakarta : Badan Perencanaan Pembangunan Nasional.

Peraturan Pemerintah Republik Indonesia Nomor 122 Tahun 2015 Tentang Sistem Penyediaan Air Minum.

Rezagama, Arya.( 2015). "Skenario Supply dan Demand Untuk Pencapaian Target Sanitasi Penyediaan Air Minum Kota Semarang Tahun 2015 Hingga 2030." Proceedings Seminar Nasional Innovation in Environmental Management, 6-11

Singarimbun, M. and Effendi, S. (1989). Metode Penelitian Survai. Yogyakarta: LP3SE. 
Putri, Setyono/ Jurnal Pembangunan Wilayah dan Kota, Vol.15, No.4, 2019, 326-339

Doi: https://doi.org/10.14710/pwk.v15i4.21639

Solichin, et. al. 2012. Dampak Laju Pertumbuhan Penduduk Terhadap Pencemaran Air Dan Kelangkaan Air Bersih. Badan Kependudukan dan Keluarga Berencana Nasional.

Syarat-Syarat Dan Pengawasan Kualitas Air. Kementrian Kesehatan. (1990). Jakarta: Kementrian Kesehatan.

USAID. (2000). “FEWS Current Vulnerability Assesment Guidance Manual”. 